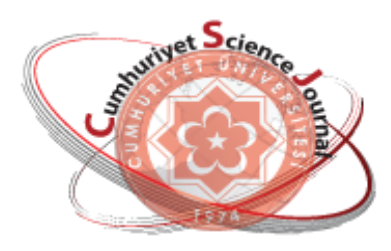

e-ISSN: 2587-246X

ISSN: $2587-2680$

\section{Cuculaniyet Seionee Journal esg}

Cumhuriyet Sci. J., Vol.38-4, Supplement (2017) 68-76

\title{
Statistical Analysis of Wind Speed Data with Weibull, Lognormal and Gamma Distributions
}

\author{
Hayriye Esra AKYUZ ${ }^{1-2 *, \text { Hamza GAMGAM }}$ \\ ${ }^{1}$ Bitlis Eren University, Faculty of Science and Arts, Department of Statistics, Bitlis / TURKEY \\ ${ }^{2}$ Gazi University, Faculty of Science, Department of Statistics, Ankara / TURKEY
}

Received: 07.03.2017; Accepted: 18.10.2017

http://dx.doi.org/10.17776/csj.358773

\begin{abstract}
In this study, average wind speed data in Bitlis for the years between 2012 and 2016 is analyzed. Average wind speed estimations for these years are obtained with the Weibull, Gamma and Lognormal distributions. Maximum Likelihood method is used in parameter estimation of these distributions. It is aimed that the most fit distribution is determined with Kolmogorov-Smirnov Goodness of Fit test, coefficient of determination and root mean square error criteria. As a result of evaluating the wind speed data with the program written in MATLAB R2009a, it was determined that average wind speed estimations are similar for each distribution, but Gamma distribution has the lowest standard deviation with the average wind speed value in August $(0.15 \mathrm{~m} / \mathrm{s})$. In modelling of the average wind speed data between 2012 and 2016, it was seen that Gamma distribution had higher coefficient of determination compared to the other distributions. Similarly, the lowest Kolmogorov-Smirnov Goodness of Fit test statistic and root mean square error value are obtained for Gamma distribution. As a result, it is recommended that Gamma distribution is used in modelling the wind speed data of Bitlis between 2012 and 2016.
\end{abstract}

Keywords: Maximum likelihood estimator, Root mean square error, Wind speed distribution.

\section{Weibull, Lognormal ve Gamma Dağılımları ile Rüzgâr Hızı Verilerinin İstatistiksel Analizi}

Özet: Bu çalışmada 2012-2016 yılları arasında Bitlis’te ortalama rüzgâr hızı verileri analiz edilmiştir. Bu yıllar için ortalama rüzgâr hızı tahminleri Weibull, Gamma ve Lognormal dağılımları ile elde edilmiştir. Bu dağılımların parametre tahminlerinde En Çok Olabilirlik yöntemi kullanılmıştır. Kolmogorov-Smirnov uyum iyiliği testi, belirleme katsayısı ve hata kareler ortalamasının karekökü kriterleri ile en uygun dağılımın belirlenmesi amaçlanmıştır. MATLAB R2009a'da yazılan program ile rüzgâr hızı verilerinin değerlendirilmesi sonucunda her bir dağılım için ortalama rüzgâr hızı tahminlerinin benzer olduğu, buna karşılık Gamma dağılımının Ağustos ayına ait ortalama rüzgâr hızı değeri $(0.15 \mathrm{~m} / \mathrm{s})$ ile en düşük standart sapmaya sahip olduğu belirlenmiştir. 2012-2016 yılları arasındaki ortalama rüzgâr hızı verilerinin modellenmesinde Gamma dağılımının diğer dağılımlara göre daha yüksek belirleme katsayısı değerine sahip olduğu görülmüştür. Benzer biçimde en küçük Kolmogorov-Smirnov uyum iyiliği test istatistiği ve hata kareler ortalamasının karekökü değeri Gamma dağılımı için elde edilmiştir. Sonuç olarak 2012-2016 yılları arasında Bitlis iline ait rüzgâr hızı verilerinin modellenmesinde Gamma dağılımının kullanılması önerilmektedir.

Anahtar Kelimeler: En çok olabilirlik tahmin edicisi, Hata kareler ortalamasının karekökü, Rüzgar hızı dağılımı.

\footnotetext{
* Corresponding author. Email address: heakyuz@beu.edu.tr

http://dergipark.gov.tr/csj $\quad$ (C2016 Faculty of Science, Cumhuriyet University
} 


\section{INTRODUCTION}

Energy consumption increases along with the technological developments and population growth. Energy requirement is an important criteria in development of countries. In almost every aspect of daily life, fossil energy fuels are used. However, the increase in the use of fossil fuels poses a threat for people by way of air pollution, climate change and carbon emission [1]. In order to eliminate these problems, alternative energy resources such as wind, solar and geothermal energy are recommended. Unlike fossil fuels, most of these energy resources which reduce carbon emission are unlimited. As a result, these energy resources have drawn quite attention recently. Use of wind power increases day by day all around the world. In this study, wind energy is taken into consideration among various environmental energy resources.

There are two important factors in obtaining wind power. First one is choosing the location where the wind system will be installed and the second one is determining the wind speed characteristics statistically. Determining the distribution of wind speed is quite effective in calculating the wind force [2]. In the literature, Weibull distribution has been used commonly in modelling the wind speed data [3-7]. There are also studies in which different distributions are preferred in modelling these data [8-11]. Carta, Ramirez and Velazquez [12] have studied the probability distributions of wind speed in analysing the wind power. Brano et al. [13] have used seven different statistical distribution to determine the distribution of wind speed and stated that the most proper distribution among those was Burr distribution. Morgan et al. [14] have used Generalized Rayleigh, Bimodal Weibull Mixture, Kappa and Wakaby distributions for modelling the wind speed data. Kantar and Usta [10] have shown that the performance of Upper-Truncated Weibull distribution is better than Weibull distribution for estimating the distribution of wind speed.

In this study, preliminary study on wind energy potential was evaluated statistically using the monthly average wind speed data between 2012 and 2016 in Bitlis. The Weibull, Lognormal and Gamma distributions were used for modelling the wind speed data of Bitlis. Unknown parameter estimations were obtained with the Maximum Likelihood Method. Coefficient of determination and root mean square error criteria were used to obtain the distribution which provides the best fit the wind speed data.

In the following section, the distributions to be used in modelling the wind speed data are included.

\section{THEORY of WIND SPEED}

Probability density functions are used to determine the wind potential in a certain area. There are numerous distributions used in modelling the wind speed. Among the most frequently used distributions are Weibull, Lognormal and Gamma distributions. Since a distribution is in question, it is considered that wind speed is a random variable [7]. Let $v(\mathrm{~m} / \mathrm{s})$ indicate wind speed. In that case, the following expression will be valid.

$\int_{0}^{\infty} f(v) d v=1, \quad f(v)>0$

\subsection{Weibull Distribution of Wind Speed}

Weibull distribution is one of the most frequently used distributions in analysing wind speed. Probability density function for 2-parameter Weibull distribution for wind speed is as follows:

$$
f(v)=\left(\frac{k}{c}\right)\left(\frac{v}{c}\right)^{k-1} \exp \left[-\left(\frac{v}{c}\right)^{k}\right]
$$

Here $f(v)$ is the probability density function of observed wind speed $v, \mathrm{c}$ is the scale parameter with the same unit as wind speed and $\mathrm{k}$ is the nondimensional shape parameter. Cumulative distribution function of Weibull distribution is as follows [15]:

$$
F(v)=1-\exp \left[-\left(\frac{v}{c}\right)^{k}\right]
$$

The Mean and standard deviation of Weibull distribution is obtained as

$$
v_{m}=c \Gamma\left(1+\frac{1}{k}\right)
$$


and

$$
\sigma=\sqrt{c^{2}\left[\Gamma\left(1+\frac{2}{k}\right)-\left(\Gamma\left(1+\frac{1}{k}\right)\right)^{2}\right]}
$$

Here, $\Gamma($.$) means gamma function.$

\subsection{Lognormal Distribution of Wind Speed}

When the natural logarithm is taken for wind speed data which changes randomly, the situation where probability distribution is distributed normally is expressed as Lognormal distribution. Probability density function and cumulative distribution function for Lognormal distribution is as follows [15].

$\mathrm{f}(v)=\exp \left[-\frac{1}{2}\left(\frac{\ln (v)-\mu}{\sigma}\right)^{2}\right] \times \frac{1}{\sigma v \sqrt{2 \pi}}$

and

$$
F(v)=\phi\left(\frac{\ln (v)-\mu}{\sigma}\right)
$$

Here, $\sigma$ means Lognormal scale parameter and $\mu$ means location parameter. Average wind speed is expressed as follows;

$$
\bar{v}_{\text {Lognormal }}=e^{\mu+\left(\frac{\sigma^{2}}{2}\right)}
$$

This distribution fits well in many variables which are encountered in practice since random variable can only get positive value in Lognormal distribution and the distribution is positively skewed.

\subsection{Gamma Distribution of Wind Speed}

Probability density and cumulative distribution function for Gamma distribution, which can also be applied to randomly changing wind speed data by means of its flexible nature that allows applying it to various sciences, is as follows [15]

$$
f(v)=\frac{v^{k-1} \exp (-v / \theta)}{\Gamma(k) \theta^{k}}
$$

and

$$
F(v)=\frac{\Gamma_{v / \theta}(k)}{\Gamma(k)}
$$

Here, $\theta$ means scale parameter of Gamma distribution and $k$ means shape parameter. Average wind speed is expressed as;

$$
\bar{v}_{\text {Gamma }}=k \theta
$$

\subsection{Statistical Analysis of Distributions}

In this study, Kolmogorov-Smirnov Goodness of Fit test was used to test how good Weibull, Lognormal and Gamma distributions for estimating the wind speed frequency values. This test statistic value is obtained as follows:

$$
K S=\max _{1 \leq i \leq n}\left(F\left(v_{i}\right)-(i-1) / n, i / n-F\left(v_{i}\right)\right)
$$

In order to make the test results more selective, coefficient of determination $\left(\mathrm{R}^{2}\right)$ and root mean square error (RMSE) are used. These statistical values are respectively expressed as $[10,11]$ :

$$
R^{2}=1-\frac{\sum_{i=1}^{n}\left(\hat{F}\left(X_{(i)}\right)-\frac{i}{n+1}\right)^{2}}{\sum_{i=1}^{n}\left(\hat{F}\left(X_{i}\right)-\overline{\hat{F}}\left(X_{i}\right)\right)^{2}}
$$

and

$$
R M S E=\left[\frac{1}{n} \sum_{i=1}^{n}\left(\hat{F}\left(X_{(i)}\right)-\frac{i}{n+1}\right)^{2}\right]^{1 / 2}
$$

Here, $\mathrm{n}$ is the sample size, $\hat{F}$ are the estimation of cumulative distribution of consecutive observations is shown with $X_{(i)}$ and it is written as

$$
\overline{\hat{F}}=(1 / n) \sum_{i=1}^{n} \hat{F}
$$

The best fit is determined on the basis of highest $\mathrm{R}^{2}$ and lowest RMSE and KS test statistic values.

\section{MATERIAL and METHOD}

The data used in this study is the monthly average wind speed values between 2012 and 2016 and it was officially obtained from Directorate of Bitlis Meteorology. The Weibull, Lognormal and Gamma distribution functions were used in evaluation of the wind speed data with the program written in MATLAB R2009a. Parameter estimations for distributions were obtained using 
Maximum Likelihood method. KolmogorovSmirnov Goodness of Fit test, coefficient of determination $\left(\mathrm{R}^{2}\right)$ and root mean square error (RMSE) were used for determining the best fitting model. In addition, wind speed values were obtained depending on the parameters of the distribution. The results are calculated monthly and annually. Thus, a preliminary study was conducted to determine the wind speed potential in Bitlis.

\section{RESULTS and DISCUSSION}

In this study, the monthly average wind speed values between the years 2012 and 2016 in Bitlis is researched using Weibull, Lognormal and Gamma distributions and the obtained results are summarized in tables. The monthly average wind speed values recorded by Directorate of Bitlis Meteorology are given in Table 1.

Table 1. Monthly and annual average wind speed values.

\begin{tabular}{lcccccc}
\hline Months & $\mathbf{2 0 1 2}$ & $\mathbf{2 0 1 3}$ & $\mathbf{2 0 1 4}$ & $\mathbf{2 0 1 5}$ & $\mathbf{2 0 1 6}$ & $\begin{array}{c}\text { Average of Long Years } \\
(\mathbf{2 0 1 2 - 2 0 1 6 )}\end{array}$ \\
\hline January & 4.1 & 3.7 & 3.1 & 3.0 & 3.6 & $\mathbf{3 . 5}$ \\
February & 3.6 & 2.8 & 2.7 & 2.7 & 2.8 & $\mathbf{2 . 9}$ \\
March & 4.0 & 3.4 & 3.0 & 2.9 & 3.4 & $\mathbf{3 . 3}$ \\
April & 2.6 & 3.5 & 3.4 & 3.9 & 3.2 & $\mathbf{3 . 3}$ \\
May & 3.5 & 3.1 & 3.2 & 3.2 & 3.6 & $\mathbf{3 . 3}$ \\
June & 3.5 & 2.9 & 3.0 & 2.7 & 3.3 & $\mathbf{3 . 0}$ \\
July & 3.5 & 2.9 & 3.1 & 2.8 & 2.9 & $\mathbf{3 . 0}$ \\
August & 2.6 & 3.0 & 2.8 & 2.6 & 2.6 & $\mathbf{2 . 7}$ \\
September & 2.5 & 3.2 & 3.2 & 2.4 & 2.8 & $\mathbf{2 . 8}$ \\
October & 2.5 & 3.1 & 3.2 & 2.7 & 2.5 & $\mathbf{2 . 8}$ \\
November & 2.6 & 3.1 & 2.7 & 3.0 & 3.0 & $\mathbf{2 . 9}$ \\
December & 3.5 & 2.9 & 3.0 & 2.7 & 3.1 & $\mathbf{3 . 0}$ \\
\hline Average & $\mathbf{3 . 2}$ & $\mathbf{3 . 1}$ & $\mathbf{3 . 0}$ & $\mathbf{2 . 9}$ & $\mathbf{3 . 0}$ & $\mathbf{3 . 0 4}$ \\
\hline
\end{tabular}

When the wind speed averages for long years is studied in Table 1, it was determined that August has the lowest wind speed $(2.7 \mathrm{~m} / \mathrm{s})$ and January has the highest wind speed $(3.5 \mathrm{~m} / \mathrm{s})$ on the monthly basis. Although wind speed averages are approximate on the yearly basis, it was seen that 2015 has the lowest wind speed with $2.9 \mathrm{~m} / \mathrm{s}$ and 2012 has the highest wind speed with $3.2 \mathrm{~m} / \mathrm{s}$.

The average wind speed values based on Seasonal are given in Table 2. When we look at the results in Table 2, it is understood that the autumn has the lowest wind speed $(2.84 \mathrm{~m} / \mathrm{s})$ and spring has the highest wind speed $(3.30 \mathrm{~m} / \mathrm{s})$ in Bitlis between 2012 and 2016 years. These results are also obtained diagrammatically in Figure 1.

The monthly average wind speed values of Bitlis between 2012 and 2016 are shown in Figure 2. As it can be seen in the table, Bitlis has high wind speed in spring and winter months between the years 2012 and 2016. Lowest wind speed is seen during autumn between these months.

Table 2. Average wind speed values based on Seasonal.

\begin{tabular}{lllll}
\hline Years & Winter & Spring & Summer & Autumn \\
\hline $\mathbf{2 0 1 2}$ & 3.73 & 3.36 & 3.20 & 2.53 \\
$\mathbf{2 0 1 3}$ & 3.13 & 3.33 & 2.93 & 3.13 \\
$\mathbf{2 0 1 4}$ & 2.93 & 3.20 & 2.96 & 3.03 \\
$\mathbf{2 0 1 5}$ & 2.80 & 3.33 & 2.70 & 2.70 \\
$\mathbf{2 0 1 6}$ & 3.16 & 3.40 & 2.93 & 2.76 \\
\hline Average & $\mathbf{3 . 1 4}$ & $\mathbf{3 . 3 0}$ & $\mathbf{2 . 9 4}$ & $\mathbf{2 . 8 4}$ \\
\hline
\end{tabular}




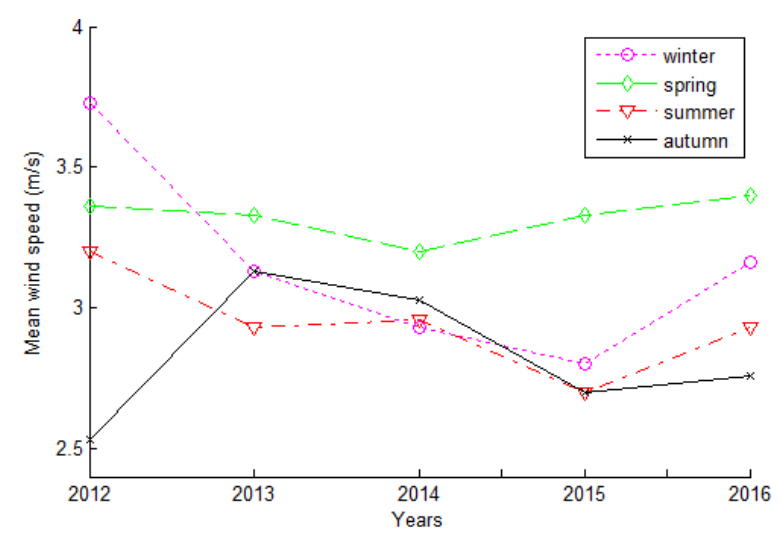

Figure 1. Average wind speed values between the years 2012 and 2016.

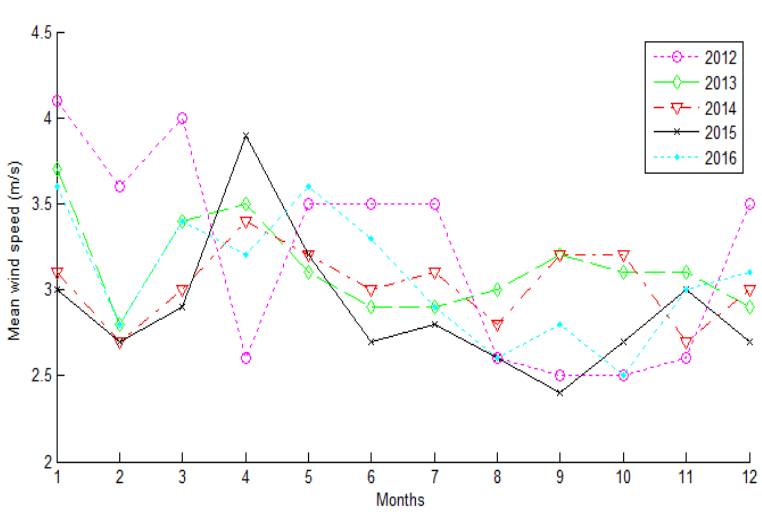

Figure 2. Monthly average wind speed values.

Table 3. Characteristics of distributions and monthly average wind speed estimations.

\begin{tabular}{|c|c|c|c|c|c|c|c|c|c|c|c|c|}
\hline \multirow[b]{2}{*}{ Months } & \multicolumn{4}{|c|}{ Weibull } & \multicolumn{4}{|c|}{ Lognormal } & \multicolumn{4}{|c|}{ Gamma } \\
\hline & $\mathrm{sd}^{* *}$ & $\hat{c}$ & $\hat{k}$ & $\hat{V}_{W}$ & $\mathrm{sd}$ & $\hat{\mu}$ & $\hat{\sigma}$ & $\hat{V}_{L}$ & $\mathrm{sd}$ & $\hat{\theta}$ & $\hat{k}$ & $\hat{V}_{G}$ \\
\hline January & 0.42 & 3.68 & 9.67 & 3.49 & 0.45 & 1.24 & 0.12 & 3.50 & 0.40 & 0.04 & 74.68 & 3.50 \\
\hline February & 0.43 & 3.08 & 7.82 & 2.90 & 0.35 & 1.06 & 0.12 & 2.92 & 0.32 & 0.03 & 80.18 & 2.92 \\
\hline March & 0.45 & 3.51 & 8.83 & 3.32 & 0.42 & 1.19 & 0.12 & 3.34 & 0.38 & 0.04 & 76.65 & 3.34 \\
\hline April & 0.88 & 3.79 & 4.40 & 3.45 & 0.95 & 1.21 & 0.26 & 3.48 & 0.82 & 0.19 & 17.46 & 3.46 \\
\hline May & 0.22 & 3.41 & 18.38 & 3.31 & 0.21 & 1.19 & 0.06 & 3.32 & 0.19 & 0.01 & 296.96 & 3.32 \\
\hline June & 0.31 & 3.21 & 11.84 & 3.07 & 0.31 & 1.12 & 0.10 & 3.08 & 0.28 & 0.02 & 117.05 & 3.08 \\
\hline July & 0.31 & 3.16 & 11.57 & 3.02 & 0.27 & 1.10 & 0.08 & 3.04 & 0.24 & 0.01 & 155.62 & 3.04 \\
\hline August & 0.20 & 2.80 & 16.49 & 2.71 & 0.17 & 0.99 & 0.06 & 2.72 & 0.15 & 0.01 & 298.02 & 2.72 \\
\hline September & 0.34 & 2.97 & 9.76 & 2.82 & 0.38 & 1.02 & 0.13 & 2.82 & 0.33 & 0.04 & 69.60 & 2.82 \\
\hline October & 0.32 & 2.93 & 10.46 & 2.79 & 0.33 & 1.02 & 0.11 & 2.80 & 0.29 & 0.03 & 90.38 & 2.80 \\
\hline November & 0.18 & 2.96 & 19.07 & 2.88 & 0.22 & 1.05 & 0.07 & 2.88 & 0.18 & 0.01 & 216.40 & 2.88 \\
\hline December & 0.31 & 3.16 & 11.48 & 3.02 & 0.29 & 1.10 & 0.09 & 3.04 & 0.26 & 0.02 & 134.954 & 3.04 \\
\hline Average & & & & 3.06 & & & & 3.07 & & & & $\mathbf{3 . 0 7}$ \\
\hline
\end{tabular}

: 2012-2016 long years average wind speed values are used, ${ }^{* *}$ :standard deviation

Characteristic values of distributions according to months and average wind speed estimation of each month are given in Table 3. Although all three distributions have similar standard deviation values, it was determined that Gamma distribution has the lowest deviation with $0.15 \mathrm{~m} / \mathrm{s}$ value in August. According to Table 3, while the estimation values of shape parameter $(\hat{k})$ vary between 17.46 $\mathrm{m} / \mathrm{s}$ and $298.02 \mathrm{~m} / \mathrm{s}$ in the 12-month period, the estimation values of scale parameter $(\hat{\theta})$ vary between $0.01 \mathrm{~m} / \mathrm{s}$ and $0.19 \mathrm{~m} / \mathrm{s}$. These are the April and July values. It was seen that the estimation values of shape parameter vary between $4.40 \mathrm{~m} / \mathrm{s}$ and $19.07 \mathrm{~m} / \mathrm{s}$ and that the estimation values of scale parameter vary between $2.80 \mathrm{~m} / \mathrm{s}$ and 3.79 $\mathrm{m} / \mathrm{s}$ for Weibull distribution. Similarly, while the estimation values of location parameter $(\hat{\mu})$ vary between $0.99 \mathrm{~m} / \mathrm{s}$ and $1.24 \mathrm{~m} / \mathrm{s}$, the estimation scale parameter $(\hat{\sigma})$ vary between $0.06 \mathrm{~m} / \mathrm{s}$ and $0.26 \mathrm{~m} / \mathrm{s}$ for Lognormal distribution. It is seen that the monthly average speeds given in Table 1 are similar to the estimated wind speed values given in Table 3, but the results obtained using the Gamma distribution which has a lower standard deviation are more consistent. In addition, it was determined that the estimation of scale parameters show smaller changes compared to the estimation of shape parameters. $\mathrm{k}$ shape parameter shows the peak of wind speed distribution. In some studies, it is known that shape parameter has smaller changes 
depending on the wind conditions [16,17]. When average wind speeds are examined, the average wind speed obtained with Weibull distribution varies between $2.71 \mathrm{~m} / \mathrm{s}$ and $3.49 \mathrm{~m} / \mathrm{s}$ and average wind speed is $3.06 \mathrm{~m} / \mathrm{s}$. The average wind speed obtained with Lognormal distribution varies between $2.72 \mathrm{~m} / \mathrm{s}$ and $3.50 \mathrm{~m} / \mathrm{s}$ and average wind speed is $3.07 \mathrm{~m} / \mathrm{s}$. Similarly, the average wind speed obtained with Gamma distribution varies between $2.72 \mathrm{~m} / \mathrm{s}$ and $3.50 \mathrm{~m} / \mathrm{s}$ and average wind speed is $3.07 \mathrm{~m} / \mathrm{s}$. January has the highest average wind speed for all three distributions.

Table 4. Characteristics of distributions and annual average wind speed estimations.

\begin{tabular}{|c|c|c|c|c|c|c|c|c|c|c|c|c|}
\hline \multirow[b]{2}{*}{ Years } & \multicolumn{4}{|c|}{ Weibull } & \multicolumn{4}{|c|}{ Lognormal } & \multicolumn{4}{|c|}{ Gamma } \\
\hline & sd" & $\hat{c}$ & $\hat{k}$ & $\hat{V}_{W}$ & sd & $\hat{\mu}$ & $\hat{\sigma}$ & $\hat{V}_{L}$ & sd & $\hat{\theta}$ & $\hat{k}$ & $\hat{V}_{G}$ \\
\hline 2012 & 0.60 & 3.43 & 6.10 & 3.19 & 0.66 & 1.13 & 0.20 & 3.19 & 0.59 & 0.12 & 26.32 & 3.18 \\
\hline 2013 & 0.32 & 3.26 & 11.52 & 3.11 & 0.26 & 1.13 & 0.08 & 3.13 & 0.25 & 0.02 & 143.03 & 3.13 \\
\hline 2014 & 0.22 & 3.12 & 16.77 & 3.03 & 0.21 & 1.10 & 0.07 & 3.03 & 0.20 & 0.01 & 214.80 & 3.03 \\
\hline 2015 & 0.78 & 3.22 & 4.20 & 2.93 & 0.53 & 1.07 & 0.17 & 2.96 & 0.52 & 0.09 & 29.96 & 2.96 \\
\hline 2016 & 0.38 & 3.22 & 9.80 & 3.06 & 0.36 & 1.11 & 0.11 & 3.06 & 0.35 & 0.04 & 76.49 & 3.06 \\
\hline \multicolumn{4}{|c|}{ Average } & 3.06 & & & & 3.07 & & & & 3.07 \\
\hline
\end{tabular}

Table 4 shows the parameter estimation values and average wind speed estimations per years for all three distributions. It was determined that these results are consistent with the results obtained in Table 3. Each one of the Weibull, Lognormal and Gamma distributions has similar standard deviations. Similarly, average wind speed estimations are also consistent with each other.
However, it was seen that Gamma distribution has the lowest standard deviation with $0.20 \mathrm{~m} / \mathrm{s}$ value. In addition, when the Table 4 is examined in terms of average wind speed, the highest wind speed was seen in 2012 and lowest wind speed was seen in 2015.

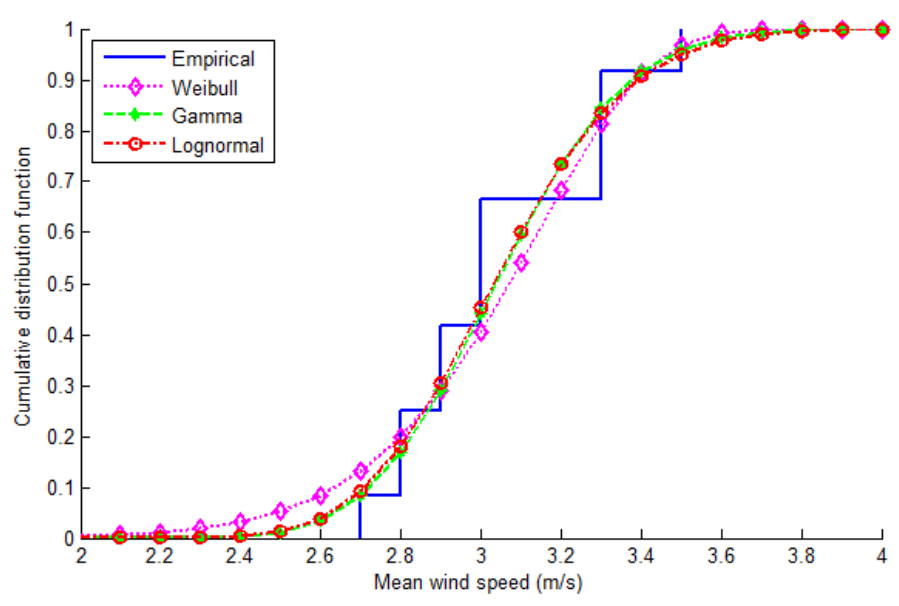

Figure 3. Cumulative distribution function of average wind speed estimations obtained with Weibull, Gamma and Lognormal distributions.

On the graphical presentation of modelling of the wind speed data, in other words on average wind speed histogram, the cumulative distribution function curve for Weibull, Gamma and Lognormal models are seen in Figure 3. When the cumulative distribution functions are examined, it was determined that all three distributions have yielded similar results. The difference between the estimations and observation values can be seen clearly. 
Table 5. Kolmogorov-Smirnov Goodness of Fit test statistic and $p$-values.

\begin{tabular}{llccccc}
\hline & & $\mathbf{2 0 1 2}$ & $\mathbf{2 0 1 3}$ & $\mathbf{2 0 1 4}$ & $\mathbf{2 0 1 5}$ & $\mathbf{2 0 1 6}$ \\
\hline \multirow{2}{*}{ Weibull } & KS & 0.2564 & 0.2385 & 0.2072 & 0.3121 & 0.1186 \\
& $p$-value & 0.3483 & 0.4349 & 0.9240 & 0.1548 & 0.9884 \\
\hline Gamma & KS & 0.2952 & 0.2075 & 0.2048 & 0.2847 & 0.1053 \\
& $p$-value & 0.2016 & 0.6087 & 0.6843 & 0.2357 & 0.9972 \\
\hline \multirow{2}{*}{ Lognormal } & KS & 0.2972 & 0.2309 & 0.2055 & 0.2916 & 0.1127 \\
& $p$-value & 0.2080 & 0.6478 & 0.6441 & 0.2841 & 0.9996 \\
\hline
\end{tabular}

Table 5 includes the KS test statistics values of the goodness of fit test for the fitness of average wind speed data to Weibull, Gamma and Lognormal distribution and $p$-values which are used in testing the significance of these values. The best fit is evaluated with the minimum KS test statistic value.
According to these results, Gamma distribution has the lowest KS test statistic value between 2012 and 2016.

Table 6. $\mathrm{R}^{2}$ and RMSE values for distributions.

\begin{tabular}{llccccc}
\hline & & $\mathbf{2 0 1 2}$ & $\mathbf{2 0 1 3}$ & $\mathbf{2 0 1 4}$ & $\mathbf{2 0 1 5}$ & $\mathbf{2 0 1 6}$ \\
\hline \multirow{2}{*}{ Weibull } & $\mathrm{R}^{2}$ & 0.9995 & 0.9954 & 0.9961 & 0.9866 & 0.9994 \\
& $R M S E$ & 0.0074 & 0.0183 & 0.0180 & 0.0220 & 0.0076 \\
\hline \multirow{2}{*}{ aamma } & $\mathrm{R}^{2}$ & 0.9998 & 0.9971 & 0.9994 & 0.9902 & 1.0000 \\
& $R M S E$ & 0.0047 & 0.0155 & 0.0072 & 0.0216 & 0.0020 \\
\hline \multirow{2}{*}{ Lognormal } & $\mathrm{R}^{2}$ & 0.9996 & 0.9967 & 0.9987 & 0.9899 & 0.9990 \\
& $R M S E$ & 0.0052 & 0.0169 & 0.0106 & 0.0219 & 0.0024 \\
\hline
\end{tabular}

Table 6 includes $\mathrm{R}^{2}$ and RMSE values based on Maximum Likelihood Estimators for Weibull, Gamma and Lognormal distributions. According to these results, although similar results are obtained for all three distributions, lowest RMSE and highest $\mathrm{R}^{2}$ value are obtained for Gamma distribution. As a conclusion, it is seen that Gamma distribution provides better modelling in terms of $\mathrm{R}^{2}$ and RMSE criteria. Given that $\mathrm{R}^{2}$ value can be maximum 1.0000 , it is understood that Gamma distribution shows very high sensitivity with this value of 2016. While there are results which support our study in the literature [18], there are also studies in which Weibull distribution yielded better results [1, 7, 19-22].

\section{CONCLUSIONS}

In this study, the estimation of parameters of distributions are obtained with Maximum Likelihood method. Monthly average wind speed data between 2012 and 2016 is obtained by means of obtaining necessary permits from Directorate of
Bitlis Meteorology. Weibull, Lognormal and Gamma distributions are used in modelling this data. When the obtained results are examined, it was seen that 2015 has the lowest wind speed with $2.9 \mathrm{~m} / \mathrm{s}$ value and 2012 has the highest wind speed with $3.2 \mathrm{~m} / \mathrm{s}$ value. Seasonally, it was determined that the autumn has the lowest $(2.84 \mathrm{~m} / \mathrm{s})$ and spring has the highest $(3.30 \mathrm{~m} / \mathrm{s})$ average wind speed. As a result of parameter estimations for all three distributions, it was determined that average wind speed estimations are similar, but Gamma distribution has the lowest standard deviation with the average wind speed value $(0.15 \mathrm{~m} / \mathrm{s})$ in August. In the goodness of fit test of average wind speed data for fitness to Weibull, Gamma and Lognormal distributions, Kolmogorov-Simirnov Goodness of Fit Test is used. Gamma distribution yielded lower value (0.1053) compared to the other distributions. When the distributions are compared in terms of coefficient of determination $\left(\mathrm{R}^{2}\right)$ and root mean square error (RMSE) criteria, highest $\mathrm{R}^{2}$ and lowest RMSE values are obtained for Gamma distribution. 
As a conclusion, it is recommended that Gamma distribution is used in modelling the wind speed of Bitlis between 2012 and 2016. This study is a preliminary study for obtaining information about the wind power potential and obtaining average wind speed estimations in Bitlis.

\section{REFERENCES}

[1]. Fyrippis I., Axaopoulos P.J., Panayiotou G. Wind energy potential assessment in Naxos Island, Greece Appl Energ 2010; 87:577-86.

[2]. Mohammadi K., Alavi O., Mostafaeipour A., Goudarzi N., Jalilvand M. Assessing different parameters estimation methods of Weibull distribution to compute wind power density Energ Convers Manag 2016; 108:322-35.

[3]. Arslan T., Bulut Y.M, Yavuz A.A. Comparative study of numerical methods for determining weibull parameters for wind energy potential Renew Sustain Energ Rev 2014; 40:820-5.

[4]. Andrade C.F., Neto H.F.M., Rocha P.A.C., Silva M.E.V. An efficiency comparison of numerical methods for determining Weibull parameters for wind energy applications: a new approach applied to the northeast region of Brazil Energ Convers Manag 2014; 86:8018.

[5]. Khahro S.F., Tabbassum K., Soomro A.M., Dong L., Liao X. Evaluation of wind power production prospective and weibull parameter estimation methods for Babaurband, Sindh Pakistan Energ Convers Manag 2014; 78:95667.

[6]. Werapun W., Tirawanichakul Y., Waewsak J. Comparative study of five methods to estimate weibull parameters for wind speed on Phangan Island, Thailand Energ Proc 2015; 79:976-81.

[7]. Kurban, M., Kantar, Y.M., Hocaoğlu F.O. Weibull dağılımı kullanılarak rüzgar hız ve güç yoğunluklarının istatistiksel analizi Afyon Kocatepe Univ Fen Müh Bilim Derg 2007; 7 : 205-18 (in Turkish).

[8]. Usta I., Kantar Y.M. Analysis of some flexible families of distributions for estimation of wind speed distributions Appl Energ 2012; 89:35567.

[9]. Bilir L., Imir M., Devrim Y., Albostan A. An investigation on wind energy potential and small scale wind turbine performance at Incek region -Ankara, Turkey Energ Convers Manag 2015; 103:910-23.

[10].Kantar Y.M., Usta I. Analysis of the uppertruncated weibull distribution for wind speed Energ Convers Manag 2015; 96:81-8.

[11].Akgül, F. G., Şenoğlu, B., Arslan, T. An alternative distribution to Weibull for modeling the wind speed data: Inverse Weibull distribution Energ Convers Manag 2016; 114:234-40.

[12].Carta J.A., Ramirez P., Velazquez S. A review of wind speed probability distributions used in wind energy analysis Case studies in the Canary Islands Renew Sustain Energ Rev 2009; 13:933-55.

[13].Brano V.L., Orioli A., Ciulla G., Culotta S. Quality of wind speed fitting distributions for the urban area of Palermo, Italy Renew Energ 2011; 36:1026-39.

[14].Morgan, E. C., Lackner, M., Vogel, R. M., Baise, L. G. Probability distributions for offshore wind speeds Energ Convers Manag 2011; 52:15-26.

[15].Casella, G., Berger, R.L. Statistical inference, 2nd ed., Duxbury Thomson Learning, USA, 2001.

[16].Parajuli, A. A statistical analysis of wind speed and power density based on weibull and rayleigh models of Jumla, Nepal Energ Power Eng 2016; 8:271-82.

[17].Ahmed, S.A. Comparative study of four methods for estimating weibull parameters for Halabja, Iraq Int J Phys Sci 2013; 8:186-92.

[18].Mert, İ., Karakuş, C. Antakya bölgesinde rüzgâr gücü yoğunluğu ve rüzgâr hızı dağılımı parametrelerinin istatistiksel analizi Politeknik Derg 2015; 18:35-42 (in Turkish).

[19].Oner, Y., Ozcira, S., Bekiroglu, N., Senol, I. A comparative analysis of wind power density prediction methods for Çanakkale, Intepe Region, Turkey Renew Sustain Energ Rev 2013; 23:491-502. 
[20].Islam, M.R., Saidur, R., Rahim, N.A. Assessment of wind energy potentiality at Kudat and Labuan, Malaysia using weibull distribution function Energ 2011; 36:985-92.

[21].Pishgar-Komleh, S.H., Keyhani, A., Sefeedpari, P. Wind speed and power density analysis based on weibull and rayleigh distributions (A case study: Firouzkooh County of Iran) Renew Sustain Energ Rev 2015; 42:313-22.

[22].Dhunny, A.Z., Lollchund, M.R., Boojhawon, R., Rughooputh, S.D.D.V. Statistical modelling of wind speed data for Mauritius Int J Renew Energ Research 2014; 4:1056-64. 